\title{
ADAPTING INTERNATIONAL EXPERIENCE TO THE DEPOSIT GUARANTEE SYSTEM IN UKRAINE
}

\author{
Ihor Alyeksyeyev, Andriana Mazur \\ Lviv Polytechnic National University, Lviv, Ukraine \\ e-mails: ihor.v.alieksieiev@lpnu.ua; andriana.v.mazur@lpnu.ua
}

(C) 2018 Ihor Alyeksyeyev, Andriana Mazur

This is an open access article distributed under the Creative Commons Attribution-NonCommercial-NoDerivs license (http://creativecommons.org/licenses/by-nc-nd/3.0/)

DOI: 10.15611/fins.2018.1.01

JEL Classification: G280, G210, G320

\begin{abstract}
The research objective of the article is the substantiation of methodological and applied recommendations for improving deposit guarantee system in Ukraine in view of the international experience. The study object is the deposit guarantee system management in the framework of reforming the Ukrainian legislation aimed at establishing a mechanism of deposits guaranteeing. During the research there were used such methods as: dialectical method and methods of analysis and synthesis - to study the features of deposit guarantee systems of developed countries, the characteristics of mechanism for returning deposits and international law peculiarities; statistical method - to analyze the indicators of banking system in Ukraine and credit unions (CU), for empirical determining CU to banks indicator ratio as well; structural and logical analysis - to develop theoretical and methodological principles of forming effective deposits guaranteeing mechanism in Ukraine. The need to ensure the system of deposits guaranteeing not only to individuals but also to individual-private entrepreneurs and legal entities was established. This will facilitate the development of small and medium businesses in the country. There were analyzed peculiarities of credit unions activity in Ukraine in the context of reforming the banking system. The possibility of including the credit unions to the deposit guarantee system of Ukraine by the example of the EU countries and the world was substantiated. There were characterized necessary amendments to the national legislation in the field of deposit guaranteeing and the effective mechanisms for their implementation were proposed.
\end{abstract}

Keywords: Deposit Guarantee System, Deposit Guarantee Fund, household deposit, deposit ensuring, credit unions (CU). 
Ihor Alyeksyeyev, Andriana Mazur

\author{
A deposit insurance system is like a nuclear power plant. \\ If you build it without safety precautions, you know it's going \\ to blow you off the face of the earth. And even if you do, you can't
}

be sure it won't.

L. William Seidman

\title{
1. Introduction
}

The state deposit insurance system is not common everywhere in the world. The bankruptcy of the banks ceased to be a rare occurrence, as evidenced by the crises of the last decades. But the savings depositors need to return loss somehow - offset, in such cases, their mission is to fulfill the deposit insurance system.

A similar system operates in nearly 70 countries around the world, the rest are on the stage of careful preparation for its creation. In China, this system started functioning in March last year. Almost in every state there are some nuances and features of the deposit insurance organization. In general there are 4 basic types of systems that can be considered as an example for our country.

National Bank of Ukraine continues the cleaning of the financial system - market exit of the banks, with a significant reduction in the number of participants in the financial system. Dozens of banks are liquidated, their customers - physical persons are compensated within 200,000 hryvnias (UAH), while investors - legal entities do not have any guarantees to protect their funds in the banks.

Meanwhile, in developed countries the guarantee on bank deposits is also associated with legal entities. Without such guarantees it is impossible to imagine the formation of a stable and strong middle class. The main question is under what circumstances it is possible to create a system of guarantees for deposits which would apply to all depositors of banks. If we plan to create a stable and reliable banking system in Ukraine, this issue will sooner or later be discussed at the highest governing level.

The system of deposit guarantee in Ukraine operates according to the Law of Ukraine "On Households Deposit Guarantee System" of February 23, 2012, Ref. number 4452-VI.

The purpose of this Law is to protect the rights and legitimate interests of bank depositors, strengthen the public trust in the Ukrainian banking system, stimulate investments in the Ukrainian banking system, and ensure an efficient procedure of insolvent bank resolution and liquidation of banks [The Law of Ukraine "On Households... 2012].

The Deposit Guarantee Fund (hereinafter - DGF) is a specialized government institution of public administration in the sphere of deposit guarantee and bank resolution. The fund is established with the purpose of protecting the rights of individual depositors (natural persons) in the Ukrainian banks. The major objective of 
the fund is to ensure the functioning of the household deposit guarantee system and insolvent banks resolution. To exercise its main objective, the DGF shall exercise the following functions as prescribed by this law [Deposit Guarantee Fund... 2016]:

1) maintain a register of the DGF participants,

2) accumulate funds from the sources determined by Art. 19 of this Law, and control the completeness and the timeliness of each DGF participant's contributions payment,

3) invest the DGF funds in the government securities of Ukraine,

4) organize deposits payout in case of a decision regarding the withdrawal of the banking license or liquidation of a bank,

5) regulate the participation of banks in the household deposits guarantee system,

6) take part in inspections of problem banks have upon a proposal of the National Bank of Ukraine,

7) apply financial sanctions and impose administrative fines to banks and their managers,

8) resolve insolvent banks through the provisional administration and liquidation of banks, transfer assets and liabilities of an insolvent bank, sell an insolvent bank, or establish and sell a bridge bank,

9) audit banks to ensure their compliance with the household deposits guarantee system legislation,

10) provide financial support to an assuming bank,

11) forecast potential costs of the DGF for insolvent banks resolution and deposits payout.

\section{Reforming the deposit guarantee system: protecting the interests of legal entities}

One of the main features which may characterize the system of national deposit guaranteeing are reimbursable contributions of individuals, and that this function is assigned only to banks, excluding the possibility of its implementation by other financial institutions.

There are many views on the formation and possible further improvement of the deposit guarantee system in Ukraine. We believe we should pay attention to the discussion that unfolded in Ukraine and abroad based on the need to spread guarantees refund of deposits and other categories of investors: individuals - entrepreneurs and legal entities. Scientists (supporters of one or another position) are not always arguing their positions and analyzing the problem in the narrow framework [Boichuk 2015].

Thus, according to the Russian scientist O. Turbanov: "Both individuals, individuals - entrepreneurs and legal entities have equal rights of claims to the bank [...]. These subjects should have equal opportunities to protect their rights, including at least a minimum level of guarantees to recover their deposits" [Turbanov (ed.) 2004]. The undisputed fact is that the main task of deposit guaranteeing is the protection 
of the least financially educated deposit holders (and those are actually individuals) from losing their money in case of bank insolvency. This is actually admitted by the Financial Stability Forum [Pospelova 2007].

This means that the primary function of the deposit guarantee system is the social function. However, this is not the only feature that is inherent in the system. Also its economic component should be identified, which is to provide the economy with financial resources including financial resources owned by individual entrepreneurs and legal entities. The Financial Stability Forum ${ }^{1}$ among the major challenges that must be addressed in the system of bank deposits guarantees also defining the promoting stability of financial system [The Financial Stability Forum 2016], which largely depends on individuals - entrepreneurs and legal entities.

According to another Russian scientist - economist D. Kolchanov, "drawing on the legislation of Eastern Europe and the Baltic countries the standards for facilities expansion of insurance coverage including the deposits of private entrepreneurs will achieve the effect of incentives to increase savings activity, and will display one of the forms of small business state support" [Kolchanov (ed.) 2007].

Ukrainian scientist-economist V. Ogienko, justifying the necessity of extending the deposit guarantee system for legal entities, recalls the same opportunity to strengthen the financial stability of commercial banks to increase the capitalization of the Fund to reduce the risk of business activities. In this case, the extension of guarantees on deposits of legal entities a scientist sees as the future development functions of the state guarantee to protect the private property of citizens and entrepreneurs [Ogienko (ed.) 2005]. According to T. Mazur, a justification to extend the deposit guarantee system to legal entities is wrong because it does not correspond to the objectives of introducing deposit guarantee systems (such systems are not to reduce business risks, but in order to protect the rights and interests of small depositors). Moreover, she considers that V. Ogienko did not take into account that such an increase of the Fund capitalization, at the same time increases the amount of its possible costs.

The research of the international practice in this area confirms that there are two main models which are provided by national legislation - narrow model, when guarantees are provided only for individual deposits (Russia, Belarus, Moldova, Latvia, Lithuania, Macedonia, Turkey) and the wide one - when the guarantees are provided for both deposits of individuals and of legal entities (Great Britain, Greece, Denmark, Spain, Italy, Portugal, Finland, France, Sweden) (Table 1).

Thus as we can see we are drawing our system of deposit ensured from the legislation of Eastern Europe, which provides guarantees only for household individual

1 The Financial Stability Forum (FSF) was a group consisting of major national financial authorities such as finance ministries, central bankers, and international financial bodies. 24 October 2016 was held the Eleventh Meeting of the Financial Stability Board Regional Consultative Group for Europe. On 28 August 2013, the FSB published a consultative document on an Assessment Methodology for the Key Attributes of Effective Resolution Regimes for Financial Institutions: http:// www.fsb.org/2013/08/r_130828. 
Table 1. Deposit guarantee models

\begin{tabular}{|l|l|l|}
\hline \multicolumn{1}{|c|}{ Type of model } & \multicolumn{1}{|c|}{ Insurance coverage } & \multicolumn{1}{c|}{ Countries } \\
\hline Narrow model & $\begin{array}{l}\text { Individual (except individuals-private } \\
\text { entrepreneurs/sole traders) depositors }\end{array}$ & $\begin{array}{l}\text { Russia, Belarus, Moldova, Latvia, } \\
\text { Lithuania, Macedonia, Turkey }\end{array}$ \\
\hline Wide model & $\begin{array}{l}\text { Individual (including individuals- } \\
\text {-private entrepreneurs/sole traders) } \\
\text { depositors and legal entities }\end{array}$ & $\begin{array}{l}\text { Great Britain, Greece, Denmark, Spain, } \\
\text { Italy, Portugal, Finland, France, Sweden }\end{array}$ \\
\hline
\end{tabular}

Source: [http://forbes.net.ua/business/1397145-infografika-kak-rabotaet-garantirovanie-vkladov-v-raznyh-stranah].

deposits. For example, according to AEQUO research company [AEQUO], a system of guarantees applies to all categories of investors in the USA, Germany, Poland and other countries.

To compare the system of deposit guarantee in Ukraine using international experience we can analyze the main characteristics shown in Tables 2, 3 .

Table 2. Sources of financing deposit guarantee system

\begin{tabular}{|l|l|}
\hline Argentina & Private sector (regular fees and additional fees) \\
\hline United Kingdom & Private sector (regular fees) \\
\hline Germany & Private sector (initial, regular and special charges) \\
\hline USA & Private sector (initial and regular fees) \\
\hline Japan & Private sector (regular fees) \\
\hline Ukraine & $\begin{array}{l}\text { Private sector (regular and extra fees), financial assistance from the state } \\
\text { (in exceptional cases) }\end{array}$ \\
\hline
\end{tabular}

Source: [International Association... 2016].

In Poland, such a system is realized through the Bank Guarantee Fund [Bank Guarantee Fund], which is non-government in its status, but managed by the state. To perform the functions assigned to it, the financial resources fund is managed, accumulated through the formation of special funds on the balance sheets of all banks - participants of the deposit guarantee system. Mixed ownership on functional deposit protection system applied in this country allows the body to maintain public confidence in it and at the same time ensures effective use of the banks involved for the protection of deposits.

As it can be seen in Table 3, the amount of guaranteeing claims on deposits of individuals in Ukraine is much lower than the guarantee in the compared countries. We should also consider the fact of guaranteeing deposits in the national currency hryvnia. Considering the exchange quotation on the market at the current rate, the 
Table 3. Guaranteeing deposits

\begin{tabular}{|l|l|}
\hline Argentina & $\begin{array}{l}\text { Guaranteeing claims of individual and legal depositors for certain categories } \\
\text { of deposits of up to 350,000 pesos (approx. 38,500 USD) per depositor. }\end{array}$ \\
\hline $\begin{array}{l}\text { United } \\
\text { Kingdom }\end{array}$ & $\begin{array}{l}\text { Guaranteeing claims of individuals and certain categories of legal entities. } \\
\text { Guaranteed amounts vary depending on the requirements of categories (for } \\
\text { example, for deposits up to 85,000 within a single creditor at a single institution, } \\
\text { for the requirements of pension savings without restrictions). Requirements are } \\
\text { guaranteed in pounds sterling. }\end{array}$ \\
\hline Germany & $\begin{array}{l}\text { Guaranteeing claims of individuals and legal entities (with the exceptions) for the } \\
\text { sum of 100,000 euros per one creditor at single institution. }\end{array}$ \\
\hline Poland & $\begin{array}{l}\text { Guaranteeing claims of individuals and legal entities (with the exceptions) for the } \\
\text { sum of 100,000 euros per one creditor at single institution. }\end{array}$ \\
\hline USA & $\begin{array}{l}\text { Guaranteeing claims of individuals, state, other categories of legal entities and their } \\
\text { unions in the amount up to 250,000 USD per one creditor at a single institution. }\end{array}$ \\
\hline Japan & $\begin{array}{l}\text { Deposits in the national currency in the amount of up to 10 million yen per } \\
\text { depositor in one institution. Some deposits are guaranteed without any restrictions } \\
\text { on the amount. }\end{array}$ \\
\hline Ukraine & $\begin{array}{l}\text { Guaranteeing claims on deposits of individuals in the amount of 200,000 UAH per } \\
\text { depositor per bank. }\end{array}$ \\
\hline
\end{tabular}

Source: [International Association... 2016].

returned amount of guaranteeing claims is only about 6.7 thousand Euros, compared to 100 thousand - in EU countries. But given the delay in returning deposits and increasing the exchange rate, the population faces the problem of devaluation of the amounts of returned deposits.

\section{The expansion of the range of the Deposit Guarantee System - participants issue}

An interesting aspect of research is the deposit insurance spreading into the much wider range of financial institutions compared to banks and other credit organizations and financial institutions. They include, for example, credit unions, insurance companies, pension funds, mutual and investment funds, trust companies etc. Guaranteeing deposits in such institutions in Ukraine can be considered as one of directions of further legislation development in this area.

In comparison, the system of deposit guaranteeing in such countries as United Kingdom, Germany, Poland, USA and Japan is provided not only by banks but by credit unions and other financial institutions as well (Table 4).

In the process of strengthening the bank deposits guaranteeing system under circumstances where it operates on a regular and stable basis and its activity is established and well regulated, there is a tendency to expand coverage of guarantee system and other financial institutions. The reason for this may be in the convergence 
Table 4. Participants of guarantee system

\begin{tabular}{|l|l|}
\hline Argentina & Banks \\
\hline United Kingdom & Banks, insurance companies, investment companies \\
\hline Germany & Banks, insurance companies \\
\hline Poland & Banks, credit unions and some other financial institutions \\
\hline USA & Banks, insurance companies and other financial institutions \\
\hline Japan & Banks and some other financial institutions \\
\hline Ukraine & Banks \\
\hline
\end{tabular}

Source: [http://forbes.net.ua/business/1397145-infografika-kak-rabotaet-garantirovanie-vkladov-vraznyh-stranah; International Association... 2016].

nature of commercial banks and other financial institutions, as well as the desire of the state to protect a wide range of small depositors.

However, at the initial stage of forming a system providing guarantees to investors, the state should determine the range of financial institutions, which it primarily intends to provide protection to. In our case, since banks are the main financial intermediaries which attract deposits, make loans, make payments, and through which the monetary policy of the state is implemented, they should have priority comparing with other financial institutions for the inclusion into deposit insurance system. However, since the simultaneous attraction and placement of funds are performed by other financial institutions, the negative effects of their insolvency can feel a significant part of depositors. Therefore, considering the role they play in the financial system, these institutions may also be the subject to guaranteeing.

In this regard, in "Guidelines for creating effective systems of deposit insurance" developed by The Financial Stability Forum special attention is paid to the possible existence of different approaches to non-bank financial institutions that attract deposits and work with other financial instruments [International Association... 2016]. There is a number of arguments in favor of the membership distribution in the system of deposits guaranteeing for these institutions:

- the intention to avoid the existence of distorted competition between different institutions offering similar products,

- the task of promoting the stability of the financial system by covering all institutions that attract deposits or similar products,

- the desire to spread the norms of prudential regulation and supervision to all institutions mentioned above [International Association... 2016].

Today insurance companies, pension funds and credit unions successfully operate in the financial market in Ukraine. All of these organizations in their activities require individual funds in various forms (by selling insurance policies, pension contributions admission or membership fees). It should be noted that the individual funds accumulated by insurance companies, pension funds and credit unions are growing, which in turn makes the issue of protecting the rights and interests of these 
funds owners more actual. This is also due to the fact that the funds accumulated by insurance companies, pension funds and credit unions are an important source of a domestic investment in the economy. Deposits of credit institutions still remain the main direction of their placement. In this case, any expression of banking crisis would inevitably impact on their solvency, and the fact that they are legal entities means that the system of bank deposits guaranteeing is not extended on them.

EU Directive 94/19/EC of 14 May 1994 "On the system of deposit insurance" [Directive 94/19/EC of the European Parliament...], which is substantially amended by Directive 2014/49/EU of the European Parliament and of the Council of 16 April 2014 "On deposit guarantee schemes" [Directive 2014/49/EU of the European Parliament...], provides deposit guarantee for both physical and legal entities. However, the Directive also sets out a number of exceptions or limitations to guaranteeing deposits of certain categories of depositors or deposits. The list of such exclusions is clearly defined. Particularly according to paragraph 1, Art. 5 of Directive 2014/49/EU, Member States may decide that certain depositors or deposits shall be excluded from guarantee or shall be granted a lower level of guarantee. The list of exclusions includes:

1) deposits made by other credit institutions on their own behalf and for their own account;

2) deposits arising out of transactions in connection with which there has been a criminal conviction for money laundering;

3) deposits by financial institution;

4) deposits by investment firms;

5) deposits the holder of which has never been identified pursuant to Article 9 (1) of Directive 2005/60/EC, when they have become unavailable;

6) deposits by insurance undertakings and by reinsurance undertakings;

7) deposits by collective investment undertakings;

8) deposits by pension and retirement funds;

9) deposits by public authorities;

10) debt securities issued by a credit institution and liabilities arising out of own acceptances and promissory notes.

In view of the changes that should come about in the financial and credit system of Ukraine and affect the problems of the Deposit Guarantee Fund from January 01 2017, we should note the following.

Firstly, a number of financial institutions will move from the National Commission for Regulation of Financial Services Markets that is liquidated as a regulator of the financial market to the National Bank of Ukraine (NBU) and the National Securities and Stock Market Commission (NSSMSC). Specifically, credit unions (CU) will be moved to the National Bank, a regulator of their financial and credit activities.

Secondly, as it results from the first statement, the National Bank traditionally works with commercial banks, which, in contrast to the credit unions, operate with loans and deposits. On the other hand, credit unions, which also provide loans, can operate without deposits, using the shares of their members as credit resources. 
Here exists a conflict that does not happen in the practice of commercial banks. It is because credit unions which did not receive a license for deposit operations, do not have to cooperate with the Deposit Guarantee Fund, as the shares of its members are not related to deposits.

The question is whether there is a need to establish the mandatory cooperation with the Deposit Guarantee Fund for credit unions. Or otherwise: is there a financial rationale for the formation of any such a fund to ensure the safety of members of the CU shares?

The answer has to be given through clarifying the experts' misunderstanding of credit cooperation nature and objectives.

Indeed, in Ukraine, especially among specialists of banks and in a certain circle of financiers, not once has been put forward the idea to bring credit unions to the same operating rules as banks. Even to this day there is a lack of understanding of the specifics of the credit cooperative union origin and functioning as a number of stakeholders in a kind of union do not resolve common problems. A consequence of this lack of understanding can be considered the election of NBU as a regulator for this segment of the financial market. However, the election of the NBU as a regulator of credit unions is the correct decision on condition of reduction in the number of regulators since the central bank of the state is certainly closer functionally to $\mathrm{CU}$ than the National Securities and Stock Market Commission.

The authors have clarified in scientific publications the nature and specific problems of credit unions in general and particularly in Ukraine [Alieksieiev, Alieksieieva 2011]. There are enough other research publications on this topic, which not only showed the specificity of credit cooperation institutions, but also justified the need to reckon with a particular form of participation of the $\mathrm{CU}$ founders to use accumulated credit and the resulting distribution of income.

In general, credit unions should be viewed not as competitors to other credit institutions, but as an association of founders for which it is economically impractical to obtain not very large loans with too high bank interest rates. In return, with the help of credit cooperation, i.e. through credit mutual assistance, some individuals private entrepreneurs, perhaps even a limited liability companies, let alone ordinary householders, can solve simple financial problems.

According to the official information of the National Commission for Regulation of Financial Services Markets for 2016 the number of registered CU was 462 (for comparison: in 2014 there were 627 and in 2015 - 588) [http://nfp.gov.ua/content/...]. There is a slow reduction in the number of credit unions and their members (in $2014-878.7$ thousand members; 2015 - 775.0 thousand members; $2016-674.1$ thousand members of $\mathrm{CU}$ ). When the total assets of the $\mathrm{CU}$ in 2016 decreased by $4.0 \%$ compared to 2015 , the total amount of capital increased by $14.2 \%$ [Ukrainian National... 2017]. It can be viewed, on the one hand, as reducing the presence of CU on the credit market, but, on the other one, as strengthening the financial condition of some $\mathrm{CU}$ and credit cooperation in general. 
On May 1, 2017 in Ukraine there were 87 liquidated banks, 32 banks where depositors received payments, 4 banks with the interim administration, 1 bank sold to investors and 1 bank sold to the state.

Dynamics of Deposit Guarantee Fund activity in 2015-2017 is shown in Table 5.

Table 5. Data on deposits of individuals in DGF member banks in 2015-2017

\begin{tabular}{|l|r|r|r|}
\hline \multirow{2}{*}{\multicolumn{1}{|c|}{ Indicators }} & \multicolumn{3}{c|}{ Date } \\
\cline { 2 - 4 } & 01.01 .2017 & 01.01 .2016 & 01.01 .2015 \\
\hline The amount of deposits of individuals, billion UAH & 382.1 & 362.3 & 382.1 \\
\hline Number of deposits, million & 41.1 & 44.7 & 46.5 \\
\hline The average amount of the deposit, UAH & 9,298 & 8,104 & 8,213 \\
\hline The percentage of coverage for number of depositors, \% & 98.6 & 98.8 & 98.7 \\
\hline DGF financial resources, million UAH & $15,315.9$ & $14,084.4$ & $16,872.60$ \\
\hline Paid out to depositors, million UAH & $80,865.5$ & $65,929.8$ & - \\
\hline
\end{tabular}

*Calculation does not include: JSCB "Kiev" (assets and liabilities were transferred), JSC "Omega Bank" (bridge bank was established) and PJSC "ASTRA BANK" (100\% shares of the insolvent bank was sold to an investor); ${ }^{* *}$ Calculation includes: money paid out to depositors of insolvent banks before transfer of assets and liabilities to assuming/bridge bank: OJSC CB "PROMEKONOMBANK", JSC “BANK GOLDEN GATE” and PJSC "TERRA BANK”.

Source: [Deposit Guarantee... 2016].

One should also emphasize a small share of the credit unions on the financial market, compared with commercial banks. According to official information of NBU at May 1, 2017 there were 90 banks (excluding insolvent) in Ukraine, 38 of which were banks with foreign capital. The data to compare credit cooperation system with the banking system of Ukraine are presented in Table 6 .

Table 6. The indicators of Ukrainian banking system and credit unions, according to the National Commission for Regulation of Financial Services Markets

\begin{tabular}{|l|c|c|c|}
\hline \multicolumn{1}{|c|}{ Indicators } & $\begin{array}{c}\text { Banks of Ukraine, } \\
31.12 .2016\end{array}$ & $\begin{array}{c}\text { Credit unions, } \\
31.12 .2016\end{array}$ & $\begin{array}{c}\text { CU to banks indicator } \\
\text { ratio, } \%\end{array}$ \\
\hline Assets, million UAH & $1,212,812$ & $2,032.5$ & 0.168 \\
\hline Capital, million UAH & 120,038 & $1,044.4$ & 0.87 \\
\hline
\end{tabular}

Source: [Credit Union...].

Obviously, credit unions occupy a very small proportion of the financial market through their too small financial capacity. Instead, they are useful at least to 674.1 thousand of its members.

Comparing the state of credit cooperation in Ukraine, Poland and in Europe as a whole, we can present the following data (Table 7). 
Table 7. Indices of Credit Unions activity in Ukraine, Poland and Europe, at January 01, 2016

\begin{tabular}{|l|r|r|r|}
\hline \multicolumn{1}{|c|}{ Indices of Activity } & Ukraine & Poland & Europe \\
\hline Number of CU & 588 & 48 & 2,220 \\
\hline Number of members & 764,600 & $2,072,598$ & $8,351,249$ \\
\hline Assets (USD) & $86,981,987$ & $3,172,133,560$ & $23,306,191,972$ \\
\hline Penetration * & $2.5 \%$ & $7.7 \%$ & $3.4 \%$ \\
\hline
\end{tabular}

* The penetration ratio is calculated as the number of credit union members to the economically active population aged from 15 to 64 years.

Source: [Credit Union...].

The comparison of the system of credit cooperation in Ukraine, Poland and Europe as a whole demonstrates the Ukrainian system significant backlog, although the need to provide credit services in Ukraine is quite high, given the low incomes of individuals. However, low income is exactly one of the reasons for the weak crediting development not only for $\mathrm{CU}$, but also for banks. In fact small official household incomes limit credit institutions in granting loans possibilities. From the perspective of the creditor, people with low incomes have weak solvency and repayment of loans. Then it has a probable interest in such borrowers as commercial banks and the Households Deposit Guarantee Fund. Instead, such a contingent of borrowers can find support in $\mathrm{CU}$, albeit in small-scale loans usually to meet their consumer needs.

\section{Conclusions}

In summary, it is worth noting that the practical implementation of the defined measures is possible only through a phased adoption of many legislative and regulatory changes.

In Ukraine, the implementation of such a move is also possible, but we need to prepare necessary conditions, in particular, strengthening the Guarantee Fund as the center of administrative influence, and entering the differentiation of contributions from banks and investors of a progressive size compensation.

Weighing all the arguments "for" and "against" on the dissemination guarantees on deposits of individuals - entrepreneurs and legal entities we should not forget about the processes of integration of Ukraine with Europe, which is an essential part of bringing domestic laws of the country in line with EU legislation.

Recalling partly the strengthening of DGF can be solved by The Law of Ukraine No. 629-VIII [The Law of Ukraine, "On Amendments...] adopted by Parliament, as well as other regulations that are developed today. However, given the repeated negative experience of individuals, businesses and investors associated with the Ukrainian financial system, in the future there would be a change of the operating 
principle of the guarantee system, including the mandatory expansion of the system for legal entities.

Ukraine is the member of certain international organizations, such as The International Association of Deposit Insurers, Federal Deposit Insurance (USA), European Forum of Deposit Insurers, etc. Thus we have all possibilities to reform our system of deposit guaranteeing basing on the insuring deposit system of welldeveloped countries, which can provide stability and strength of financial and bank system in whole.

There are certain international legislation acts which should be taken into account while developing and elaborating national legislation in this sphere:

- Core Principles for Effective Deposit Insurance System (collaborated, agreed and published by The International Association of deposit insurers in 2014) [IADI 2014];

- the Directive of the European Parliament and the Council (the legal provisions of the Act on BGF in Poland are in full compliance).

From the financial and legal point of view there should be certain prerequisites for the practical implementation of distribution guarantees on deposits of individuals - entrepreneurs and legal entities, the main of which is the availability of fund resources. When deciding on the extension of the guarantee, the financial capabilities of both the state and most credit institutions should also be taken into account, since the guarantee fund is formed at the expense of their means.

\section{References}

AEQUO / Advising EBRD on the reform of Deposit Guarantee Fund, https:/aequo.com.ua/projects/ aequo_advises_ebrd_on the reform_of deposit guarantee_fund.

Alieksieiev I., Aliksieieva S., 2011, Kreditnye sojuzy Ukrainy: priroda i problemy, Business Inform., no. 2, vol. 1, pp. 34-36.

Bank Guarantee Fund, https://www.bfg.pl.

Boichuk T., 2015, The Legal regulation of guaranteeing and savings restoration in Ukraine, the manuscript for the scientific degree of the Candidate of Science of Law, Lviv Polytechnic National University, Lviv.

Credit Union Association Bulletin, http://www.unascu.org.ua/bulletin/61.pdf.

Deposit Guarantee Fund of Ukraine, 2016, http://www.fg.gov.ua/en.

Directive 94/19/EC of the European Parliament and the Council of 16 May 1994 on deposit guarantees schemes, Official Journal, L 135.

Directive 2014/49/EU of the European Parliament and the Council of 16 April 2014 on deposit guarantee schemes, Official Journal of the European Union, 12.6.2014, L 173/149.

http://forbes.net.ua/business/1397145-infografika-kak-rabotaet-garantirovanie-vkladov-v-raznyh-stranah.

http://nfp.gov.ua/content/richni-zviti-nackomfinposlug.html.

IADI Core Principles for Effective Deposit Insurance Systems, 2014, http://www.iadi.org/en/assets/ File/Core\%20Principles/cprevised2014nov.pdf.

International Association of Deposit Insurers, 2016, http://www.iadi.org/en. 
Kolchanov D. (ed.), 2007, The system of compulsory bank deposits insurance and the mechanism of its realization, the thesis for the scientific degree of the Candidate of Science of Economics, Tumen, p. 24.

National Bank of Ukraine, 2016, https://bank.gov.ua.

Ogienko V. (ed.), 2005, The households deposit guarantee system in Ukraine, the manuscript for the scientific degree of the Candidate of Science of Economics, Lviv, p. 19.

Pospelova M., 2007, Will the deposit guarantee system be effective? http://allpravo.ru/library/doc99p0/ instrum5281/item5282.html.

Pozhar A. (ed.), 2013, Kredytno-kooperatyvnyi Sector Ekonomiky Evropeiskyh Krain, RWC PUET, Poltava, p. 278.

Pyshnyi A., 2006, Deposit Guarantee System: Reforms are necessary and inevitable, http://gazeta.zn.ua/ ECONOMICS/sistema_garantirovaniya_vkladov_reformy_neobhodimy_i_neizbezhny.html.

The Financial Stability Forum (FSF), 2016, http://www.fsb.org.

The Law of Ukraine, "On Amendments to Certain Legislative Acts of Ukraine (on Improvement of the Deposit Guarantee System and Removal of Insolvent Banks from the Market)" of July 16, 2015, Ref. number 629-VIII, http://zakon3.rada.gov.ua/laws/show/629-viii.

The Law of Ukraine, "On Households Deposit Guarantee System" of February 23, 2012, Ref. number 4452-VI, http://zakon2.rada.gov.ua/laws/show/4452-17.

Turbanov A. (ed.), 2004, Financial and legal bases of creation and functioning of the deposit insurance system in the Russian Federation, the thesis for the scientific degree of The Doctor of Science of Law, Moscow, p. 47.

Ukrainian National Credit Union Association: Credit Union Association Bulletin, 2017, http://www.unascu.org.ua/bulletin/61.pdf.

\section{ADAPTACJA MIECDZYNARODOWEGO DOŚWIADCZENIA DO SYSTEMU GWARANTOWANIA WKŁADÓW NA UKRAINIE}

Streszczenie: Celem badania było uzasadnienie metodologicznych i technicznych zaleceń o udoskonaleniu systemu gwarantowania wkładów na Ukrainie ze względu na doświadczenie międzynarodowe. Obiektem badania było zarządanie systemem gwarantowania wkładów w ramach reformowania ustawodawstwa Ukrainy, skierowanego na utworzenie mechanizmu gwarantowania wkładów. W trakcie badania zostały wykorzystane następujące metody: metoda dialektyczna oraz metody analizy i syntezy - badania osobliwości systemu gwarantowania wkładów państw rozwiniętych, charakterystyka mechanizmu zwrotu depozytów oraz osobliwości prawa międzynarodowego; metoda statystyczna - analiza wskaźników systemu bankowego na Ukrainie oraz unii kredytowych (UK), w celu empirycznego ustalenia korelacji wskaźników UK i banków; analiza strukturalna i logiczna - rozwój teoretycznych oraz metodologicznych zasad kształtowania skutecznego mechanizmu gwarantowania wkładów na Ukrainie. Zbadano konieczność zapewnienia udziału w systemie gwarantowania depozytów nie tylko osób fizycznych, a także przedsiębiorców i osób prawnych. To sprzyja rozwojowi małych i średnich przedsiębiorstw w kraju. Przeanalizowano osobliwości działalności unii kredytowych na Ukrainie w kontekście reformowania systemu bankowego. Uzasadniono możliwość włączenia unii kredytowych do systemu gwarantowania wkładów na Ukrainie na przykładzie państw UE i świata. Scharakteryzowano niezbędne korekty do ustawodawstwa krajowego dotyczącego zakresu gwarantowania wkładów oraz zaoferowano skuteczne mechanizmy ich spełnienia.

Słowa kluczowe: system gwarantowania wkładów, fundusz gwarantowania wkładów, wkłady osób fizycznych, gwarantowanie wkładów, unie kredytowe (UK). 